\title{
DISTRIBUTION OF PEPTIDE-CONTAINING ENDOCRINE CELLS AND NEURONS IN THE GASTROINTESTINAL TRACT OF THE DOG: IMMUNOHISTOCHEMICAL STUDIES USING ANTISERA TO SOMATOSTATIN, SUBSTANCE P, VASOACTIVE INTESTINAL POLYPEPTIDE, MET-ENKEPHALIN, AND NEUROTENSIN
}

\author{
AKIRA TANGE ${ }^{1}$ \\ Second Department of Surgery, Kyoto Prefectural University of Medicine, Kyoto 602, Japan
}

\begin{abstract}
The distribution of peptide-containing endocrine cells and neurons in the stomach, duodenum, jejunum, ileum, and colon of the dog was studied with the peroxidaseantiperoxidase technique using antisera to somatostatin (SOM), substance P (SP), vasoactive intestinal polypeptide (VIP), Met-enkephalin (M-ENK), and neurotensin (NT). 1) Somatostatin-containing endocrine cells were distributed throughout all parts of the gastrointestinal tract. Met-enkephalin-containing endocrine cells were located only in the pylorus and duodenum. Neurotensin-containing endocrine cells were observed in the duodenum, jejunum, ileum and colon. Neither substance P nor VIP immunoreactivity was detected in gut endocrine cells. 2) Somatostatin, substance P, VIP, and Met-enkephalin immunoreactivity was observed also in neuronal elements throughout the gastrointestinal tract, whereas neurotensin immunoreactivity was detected only in the small intestine. Immunoreactivity to all peptides except neurotensin was found in nerve fibers and in ganglion cells located in both the myenteric and submucous plexus. No neurotensin-containing neurons were seen in any layer of the gut wall. Somatostatin-positive nerve fibers were distributed in the myenteric plexus, circular muscle, submucous plexus, and lamina propria mucosae. A large number of substance P- and VIP-positive nerve fibers were seen in all layers of the gut wall; they formed a dense network especially in the nerve plexus and lamina propria. Met-enkephalin-positive nerve fibers were also demonstrated in all layers and formed a dense network in the myenteric and submucous plexus. Neurotensin-positive nerve fibers were found in the longitudinal muscle, myenteric plexus, and circular muscle, but only a few were seen in the submucous plexus.
\end{abstract}

One of the most exciting findings in recent years has been that many of the hormonal peptides initially isolated in the brain are also present in the gut, and that several gut hormonal peptides

1 Present address: First Department of Surgery, Shiga University of Medical Science, Seta Tsukinowacho, Otsu, Shiga 520-21, Japan are also found in the brain (7). In the gut, these peptides, which have been termed brain-gut peptides (7), are located both in endocrine cells and intramural and extramural neurons.

The peptides identified in gut endocrine cells include somatostatin (SOM) $(1,3,21,25,26,32$, $34,44,46)$, substance $P(S P)(38,41,53)$, vasoactive intestinal polypeptide (VIP) $(9,10,43)$, 
enkephalin (ENK) $(2,24)$, and neurotensin (NT) $(16,20,25,40,45,52)$.

There are also ten or more distinct types of enteric intramural neurons which have been distinguished by electrophysiological, pharmacological, histochemical, and biochemical studies (for review see 19). Certain peptides reveal different functions in the enteric neuron system. Immunohistochemical studies have demonstrated that gut nerves may contain SOM, SP, VIP, ENK, gastrin/cholecystokinin, bombesin, NT and other peptides $(19,23,48,54)$. Most of these peptidergic neurons are intrinsic to the gut (48), but morphological and functional analysis is complicated by the fact that the same peptides are also present in extrinsic neurons of, for example, the vagus nerve (23).

It is worthwhile to study the distribution of both endocrine cells and neurons of the gut in the same tissue preparation. A systematical analysis of the distribution of peptide-containing neurons has been reported using rodents (48). The canine gut has been favored in the studies of the functional roles of the brain-gut peptides $(4-6,30,31,36,37,49)$. Although many studies on the morphological analysis of peptide-containing elements in the gut of this species have been reported $(3,10,16,20,24-26,30,40,41,43$, $44,46,52$ ), a systematic investigation of the peptides in both neuronal and endocrine systems through the entire gastrointestinal tract is lacking.

In the present study a detailed description of the qualitative and semiquantitative distribution of several bioactive peptides, i.e., SOM, SP, VIP, methionine-enkephalin (M-ENK), and NT in the gastrointestinal tract of the dog is given. The present results in the dog support the previous physiological and pharmacological findings on the distribution of these peptides in the dog.

\section{MATERIALS AND METHODS}

Eleven dogs of both sexes weighing 5-8 $\mathrm{kg}$ were used. They were deeply anesthetized with sodium pentobarbital (Nembutal) and perfused through the left ventricle with 1-2 I of ice-cold phosphate buffer saline (PBS; $0.1 \mathrm{M}$ phosphate buffer, $0.9 \% \mathrm{NaCl}, \mathrm{pH} 7.4$ ) followed by $3-41$ of an ice-cold fixative containing $4 \%$ paraformaldehyde, $0.3 \%$ glutaraldehyde and $0.2 \%$ picric acid in $0.1 \mathrm{M}$ sodium phosphate buffer (PB; pH 7.4). After perfusion fixation, pieces of the stomach (fundus, corpus, antrum and pylorus), the small intestine (duodenum, jejunum and ileum), and the large intestine (proximal and distal colon) were quickly removed. These were dissected into small blocks $(5-10 \mathrm{~mm}$ in size). Care was taken to avoid any damage to the mucosal and muscular layers of these specimens. They were then postfixed for $48 \mathrm{~h}$ at $4^{\circ} \mathrm{C}$ in a fixative containing $4 \%$ paraformaldehyde and $0.2 \%$ picric acid buffered with $\mathrm{PB}$. The fixed specimens were washed with $\mathrm{PB}$ containing $15 \%$ sucrose for $48 \mathrm{~h}$ at $4^{\circ} \mathrm{C}$.

Cryostat sections $20 \mu \mathrm{m}$ thick were processed for immunohistochemistry essentially as reported by Kimura et al. (29), using the unlabeled antibody peroxidase-antiperoxidase complex (PAP) developed by Sternberger (50). Free-floating sections were pretreated with $0.3 \%$ Triton X-100 for 4 days and treated with $0.1 \%$ normal bovine serum for $1 \mathrm{~h}$, and incubated with specific antisera raised in rabbits against somatostatin, substance $P$, vasoactive intestinal polypeptide, Met-enkephalin, or neurotensin for 5 days. They were then incubated with anti-rabbit goat IgG (Miles; $1: 200$ ) for $2 \mathrm{~h}$, and with PAP (Dako; $1: 200$ ) for $2 \mathrm{~h}$ at room temperature.

The characteristics of the antisera used are shown in Table 1. Each antiserum was diluted with PBS containing $0.3 \%$ Triton X-100. Specimens were washed in PBS containing $0.3 \%$ Triton X-100 before they were transferred from one serum to another. In order to inhibit the activity of endogenous peroxidase, tissue sections were treated with $0.1 \% \mathrm{H}_{2} \mathrm{O}_{2}$ and subsequently with $0.1 \%$ phenylhydrazine buffered with PBS after incubation with the peptide specific antisera (51). Finally, each antigen was rendered visible by reaction with a solution containing $0.02 \%$ diaminobenzidine and $0.015 \% \mathrm{H}_{2} \mathrm{O}_{2}$ for $10 \mathrm{~min}$ at room temperature. Stained sections were mounted on gelatin-coated glass slides, air dried, and washed with running tap water. These sections were dehydrated in a graded series of ethanol, cleared in xylene and covered with Entellan.

Control tests for the immunostaining were done by replacing a peptide-specific antiserum with a non-immunized rabbit serum, or by incubating with each peptide-specific antiserum which had been absorbed by an excess amount of each antigen $(10-100 \mu \mathrm{g} / \mathrm{ml})$.

The peptides used for the control tests were: Synthetic somatostatin, substance P, Met-enkephalin, and neurotensin obtained from Protein Research Foundation, Osaka, Japan; synthetic VIP was generously supplied by Professor N. Yanaihara, Laboratory of Bioorganic Chemistry, Shizuoka College of Pharmacy, Shizuoka, Japan. 
Table 1 Characteristics of Antisera

\begin{tabular}{|c|c|c|c|}
\hline Antisera to & Code No. & Working dilution & Source \\
\hline Somatostatin & OAL 272 & $1: 8,000$ & $\begin{array}{l}\text { Otsuka Assay Laboratories } \\
\text { Tokushima, Japan }\end{array}$ \\
\hline Substance $\mathbf{P}$ & 24410 & $1: 5,000$ & $\begin{array}{l}\text { Immuno Nuclear Corporation } \\
\text { Stilwater, MN } 55082 \text { U.S.A. }\end{array}$ \\
\hline VIP & R 502 & I : 5,000 & $\begin{array}{l}\text { Professor N. Yanaihara } \\
\text { Shizuoka College of Pharmacy } \\
\text { Shizuoka, Japan }\end{array}$ \\
\hline Met-Enkephalin & 41310 & $1: 4,000$ & $\begin{array}{l}\text { Immuno Nuclear Corporation } \\
\text { Stilwater, MN } 55082 \text { U.S.A. }\end{array}$ \\
\hline Neurotensin & R 3511 & $1: 4,000$ & $\begin{array}{l}\text { Professor N. Yanaihara } \\
\text { Shizuoka College of Pharmacy } \\
\text { Shizuoka, Japan }\end{array}$ \\
\hline
\end{tabular}

\section{RESULTS}

Endocrine cells containing somatostatin (SOM), Met-enkephalin (M-ENK), and neurotensin (NT) were distributed in various regions of the canine gut, but no endocrine cells contained substance $P$ (SP) or vasoactive intestinal polypeptide (VIP). On the other hand, neuronal elements containing SOM, SP, VIP, M-ENK, and NT were all found in the gut. These peptides were present in neuronal somata and fibers, with the exception of NT, which was found only in neuronal fibers. All these peptides could be observed without any pharmacological pretreatment with vinblastine or colchicine.

The distribution of the different peptidecontaining endocrine cells and neurons varied according to the portion of the gastrointestinal tract and the layer of the gut wall. This distribution is diagrammatically summarized in Diagram 1. As the distribution patterns of each neuronal peptide were mostly uniform throughout the digestive tract, the pattern in the jejunum is shown as a representative case. The submucous plexus in the canine stomach is so sparse and difficult to examine systematically that it was not examined in this study.

\section{Somatostatin Immunoreactivity}

Endocrine cells SOM immunoreactive endocrine cells occurred in the entire region from the stomach to the distal part of the colon (Figs. 1, a-d and 2). In the body of the stomach, these cells were scattered among the exocrine cells of the gastric glands (Fig. 1, a and b), and were predominantly located within the lower half of the mucosa. They were characteristically elongate in shape, with short processes which often formed terminal knobs (Fig. 1b). In the antrum and pylorus, the cells were mainly located within the middle third of the mucosa (Fig. 1c), and had a triangular or an ovoid shape, with a thick cytoplasmic process commonly reaching the lumen (Fig. 1d).

The SOM positive endocrine cells were also located among the cells of the intestinal glands below the crypts in the small intestine (Fig. 2). But the majority were located in the lower portions of the intestinal glands, in pyramidal or bottle-like shapes (Fig. 2). In the colon, they were scattered across the colonic glands below the crypts, in a shape similar to those found in the upper digestive tract. A rough measurement of the number of SOM-containing endocrine cells indicated that their population density decreased towards the anal side.

Neuronal elements Many intensely stained SOM immunoreactive nerve cells and varicose and non-varicose fibers were found in the myenteric plexus of the jejunum (Fig. 3). The cytoplasm of the SOM positive neurons was densely packed with immunoreactive granules, the nuclei being devoid of reaction products (Fig. 3 ). Long nerve fibers running in the myenteric plexus appeared to connect each ganglion. A few immunoreactive fibers were observed in a discrete region near the deep muscular plexus in the circular muscle of the jejunum (Fig. 4), whereas no SOM positive nerve fibers were found in the longitudinal muscle (Fig. 3). Numerous SOM-containing neuronal somata and fibers were present in the ganglia of the jejunal submucous plexuses (Fig. 5). There were no fibers 

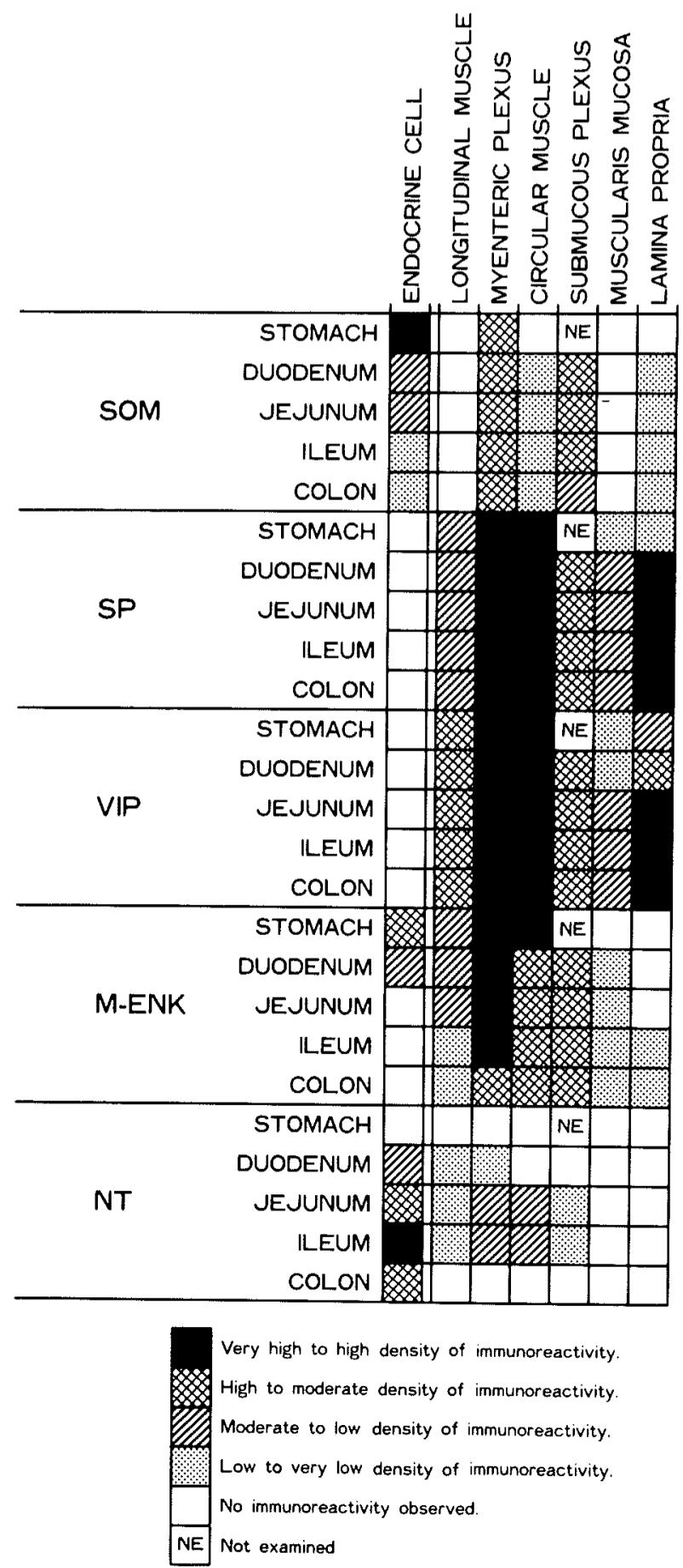

Diagram 1 Summarized representation of the density of SOM-, SP-, VIP-, M-ENK- and NT-immunoreactive endocrine cells and nerve fibers in the dog gastrointestinal tract 


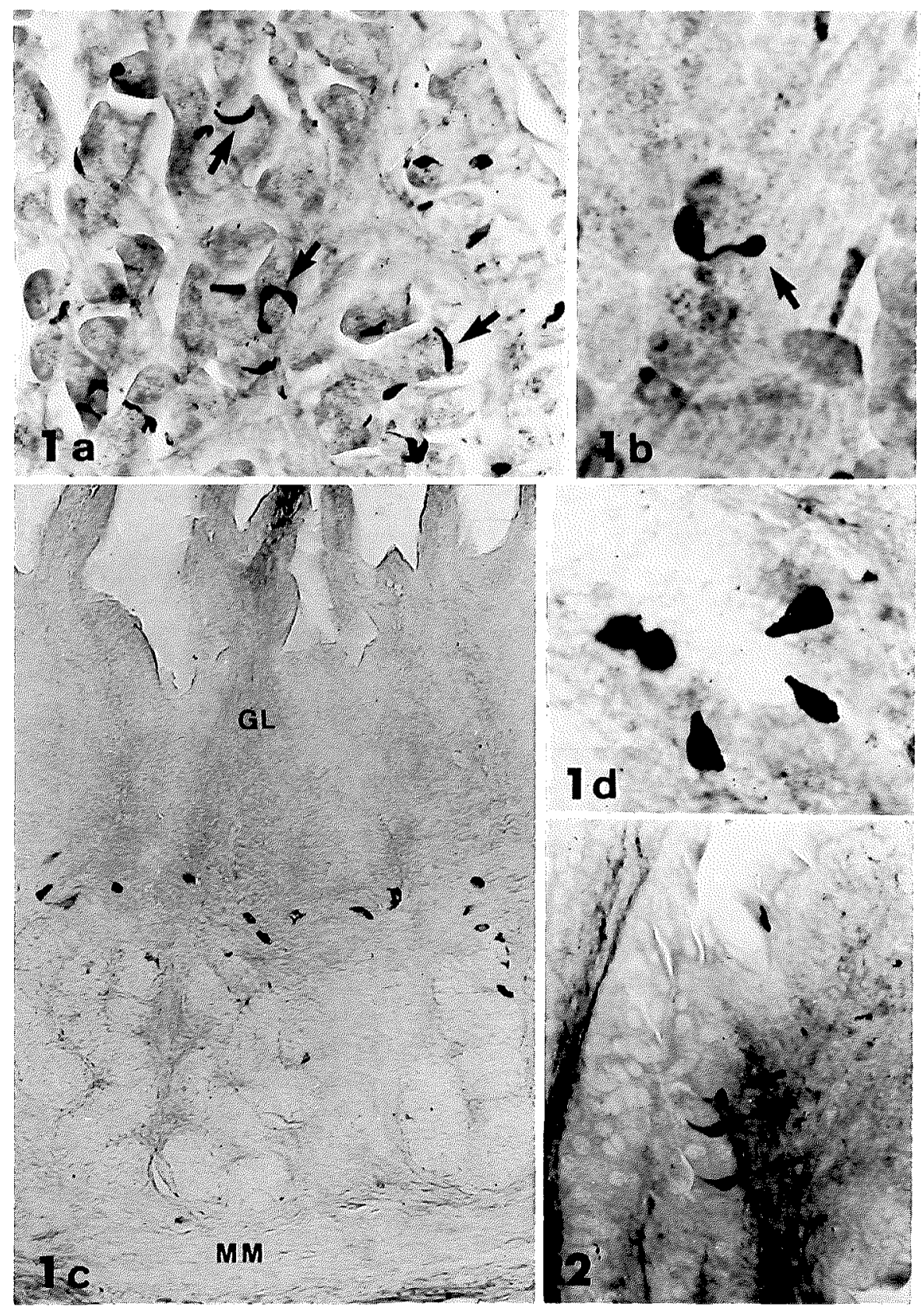

Fig. 1 SOM immunoreactivity in the stomach of the dog. a: Fundic mucosa. SOM positive cells of a characteristically elongated shape (arrows). $\times 200$. b: An SOM positive cell in higher magnification, showing a short cytoplasmic process with a terminal knob (arrow). $\times 500$. $c$ : Pyloric region. SOM positive cells are distributed in the middle third layer of the pyloric glands (GL) on the muscularis mucosae $(\mathrm{MM}) . \quad \times 130 . \mathrm{d}: \mathrm{SOM}$ positive cells of triangular or ovoid shape in the pyloric mucosa. $\times 320$ Fig. 2 SOM cells in the duodenal mucosa of the dog. Three SOM positive cells (arrows) are scattered in the epithelial layer. The cells are distributed mainly in the lower part of the duodenal glands. $\times 180$ 


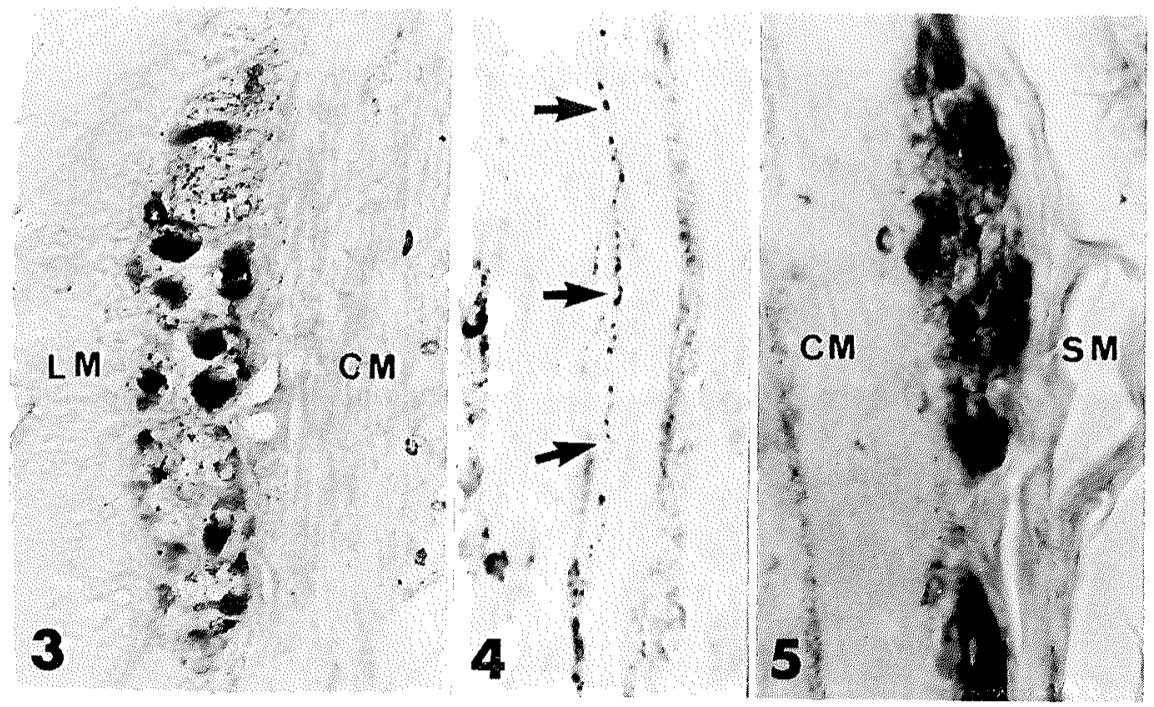

Figs. 3-5 Canine jejunal wall incubated with the antisera to SOM

Fig. 3 Numerous SOM containing perikarya and varicose fibers in the myenteric ganglion between the longitudinal (LM) and circular (CM) muscle layer. SOM positive cell bodies with dark deposits on their cellular surface. $\times 200$

Fig. 4 Circular muscle layer. Long beaded SOM nerve fibers (arrows). $\quad \times 360$

Fig. 5 Many immunostained cell bodies and nerve fibers located in the submucosal ganglion.

$\times 280$. CM, circular muscle; SM, submucosa

in the muscularis mucosae. In rare cases, SOM positive fine varicose fibers were seen in the mucosa beneath the jejunal epithelium.

\section{Substance P Immunoreactivity}

Although no SP immunoreactivity was found in the endocrine cells, SP was detected in neuronal elements in the entire gastrointestinal tract. A few SP-containing neuronal somata could be found within a single ganglion in the myenteric and submucous plexus of the jejunum (Figs. 6 and 7). Many intensely stained varicose or non-varicose nerve fibers were found in the ganglia of the myenteric plexus (Fig. 6). Here the fibers formed a dense network which surrounded the neuronal perikarya of nerve cells. Some of them appeared to make an anastomosis between neighboring ganglia of the myenteric plexus.

A relatively moderate number of SP positive nerve fibers were detected in the longitudinal muscle. Many SP immunoreactive nerve fibers derived from the myenteric plexus could be followed to the circular muscle where they usually ran parallel to the circular muscle layer (Fig. 6). In the deep muscular plexus of the circular muscle, especially thick fiber bundles stained for SP were seen.

Numerous SP positive nerve fibers were also present in the submucous plexus (Fig. 7). Some of the fibers originating from a submucosal ganglion entered another ganglion. In the mucosa, SP positive fibers were densely distributed. They penetrated the muscularis mucosae

Figs. 6-8 Canine jejunal wall incubated with antisera to SP

Fig. 6 Several immunoreactive cell bodies (arrows) and fibers in the myenteric plexus between the longitudinal (LM) and circular (CM) muscle layer. Long beaded fibers run parallel in the circular muscle layer. $\times 200$

Fig. 7 The submucosal plexus in the submucosa (SM) (arrows). Several SP positive neurons and varicose fibers can be observed. A loose network of SP positive nerve fibers occurs in the muscularis mucosae (MM) and surrounds the base of the mucosal glands (GL) to form a periglandular plexus. $\times 180$

Fig. 8 a: Numerous SP positive nerve bundles form a periglandular plexus and run toward the villi. $\times 200$. b: A network of SP positive nerve fibers underneath the epithelium (subepithelial plexus). The fibers are continuous with the periglandular plexus. $\times 200$ 


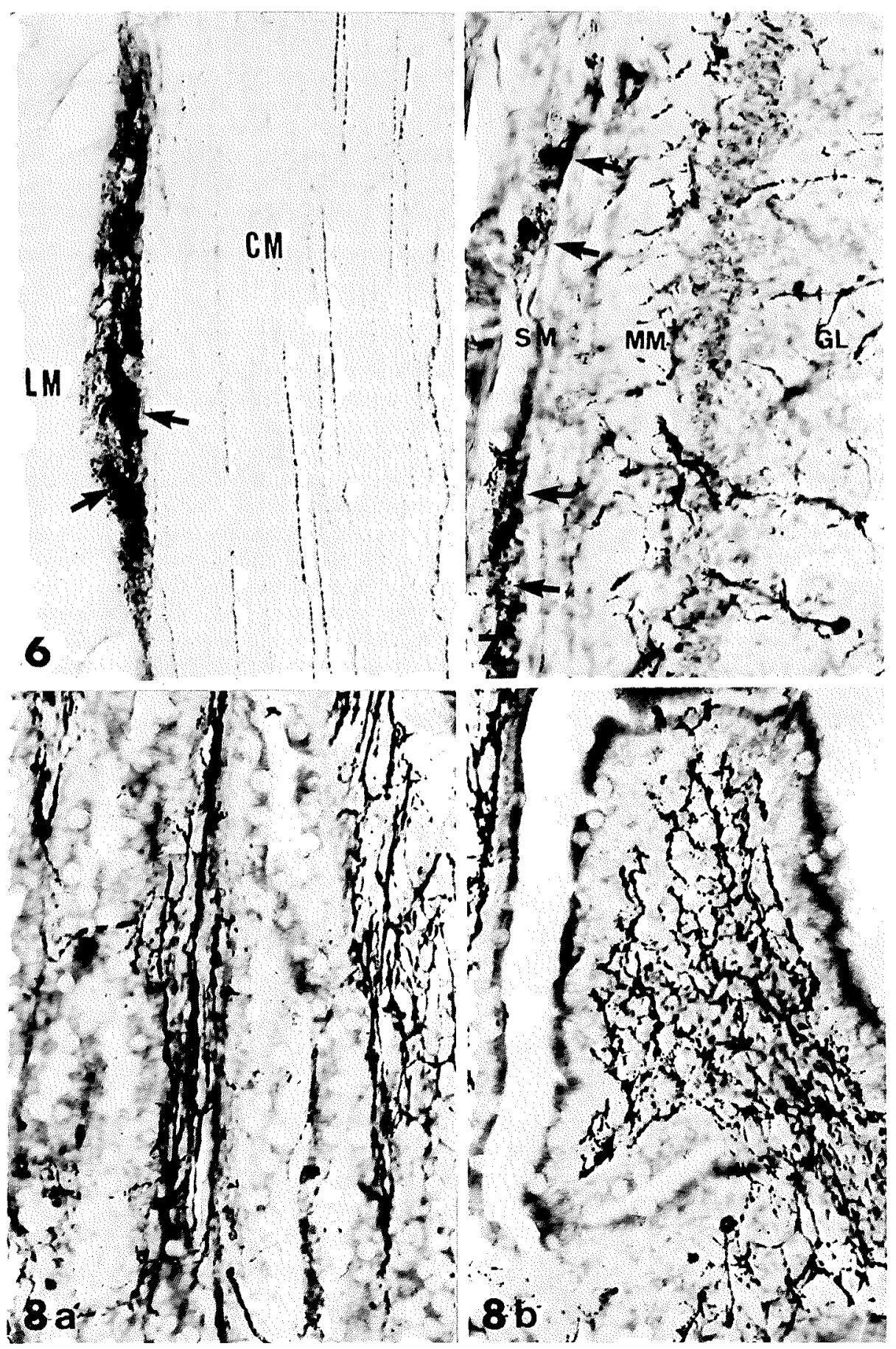

Figs. 6-8 
from the submucous plexus to form the subglandular plexus, and ramified around the bases of the glands to form a periglandular plexus (Fig. 7). Thick bundles of SP positive nerve fibers ran from these plexus to the villi beneath the glandular epithelium (Fig. 8a), where the fibers terminated in a dense network of the subepithelial plexus (Fig. 8b).

\section{Vasoactive Intestinal Polypeptide Immunore- activity}

No VIP immunoreactivity was found in any endocrine structure, but in neuronal structures VIP existed throughout the entire gastrointestinal tract. Many varicose or non-varicose nerve fibers were intensely reactive for VIP in the jejunal myenteric ganglia. These fibers formed a dense network surrounding the ganglion cells, a few of which were also stained for VIP (Fig. 9). Dense varicose fibers often formed meshwork adjacent to non-immunoreactive nerve cells (Fig. 9). The VIP fibers of the myenteric plexus ran through the neighboring ganglia. Many VIP fibers deriving from this plexus were distributed in and along the longitudinal and circular muscles (Fig. 9). They formed a thick bundle in the deep muscular plexus of the circular muscle. A plexus of the VIP fibers was seen in the ganglia of the submucous plexus; some of their perikarya contained reaction products for VIP (Fig. 10). A moderate number of VIP fibers penetrated the muscularis mucosae and joined in the subglandular plexus. They further ramified around the bases of the glands to form a periglandular plexus. The VIP fibers originating from periglandular plexuses extended towards the villi beneath the glandular epithelium (Fig. 11a), where they were scattered in a dense network of subepithelial plexus (Fig. 11b).

\section{Met-Enkephalin Immunoreactivity}

M-ENK immunoreactivity was found in both endocrine structures and neuronal elements.

Endocrine cells M-ENK immunoreactive endocrine cells were demonstrated in the pylorus and duodenum. In the pylorus, they were scattered among the epithelial exocrine cells and had a pyramidal shape (Fig. 16). Usually a small portion of their cytoplasmic extensions reached the lumen. M-ENK positive cells with a similar morphological feature were also found in the duodenal glands.

Neuronal elements M-ENK positive nerve fibers and perikarya were found in abundance in the myenteric plexus in a manner similar to those found in other peptides (SOM, SP, VIP) (Fig. 12), but only a few immunopositive fibers were located in the longitudinal muscle layer. The pattern of distribution of M-ENK positive fibers in the circular muscle and its deep muscular plexus, the submucous ganglia, and the muscularis mucosae was mostly similar to that of other peptides, viz., SP and VIP (Figs. 13-15). A small number of M-ENK immunoreactive fibers, however, did exist in the lamina propria of the ileum and colon.

\section{Neurotensin Immunoreactivity}

NT immunoreactivity was found in both endocrine cells and neuronal elements in some parts of the canine gut.

Endocrine cells NT immunoreactive endocrine cells were distributed throughout the small intestine and colon. In the small intestine these pyramidal shaped cells were scattered among the epithelial cells and were mainly located in the lower half of the mucosa (Figs. 17d and 18). Their cytoplasmic extensions closely resembled those of the other peptides. In the colon, NT immunoreactivity occurred in the epithelium, where numerous NT positive round or ovoid cells were observed in the margin of the vertical section of the mucosa (Fig. 19).

Neuronal elements Although a few NT fibers were found in the myenteric and submucous ganglia (Fig. 17, a and c), no immunoreactive NT perikarya were detected. The nerve fibers formed a loose network in the ganglia and their varicose fibers often displayed meshwork which surrounded ganglion cells. Near the myenteric plexus a few immunoreactive nerve fibers were detected in the longitudinal and circular muscle (Fig. 17b), but no fibers were seen in the mucosa.

None of the immunoreactivities described above were detectable after the control tests, i.e., in the specimens treated with non-immunized rabbit serum or with the antigen-absorbed antiserum.

\section{DISCUSSION}

\section{General Comments on the Gastrointestinal Peptides}

Diagram 1 summarizes the pattern of distribution of the reftides. On the basis of their location, these peptides may be put into three categories: 1) peptides found in both endocrine cells and neurons; 2) peptides found only in neurons; and 


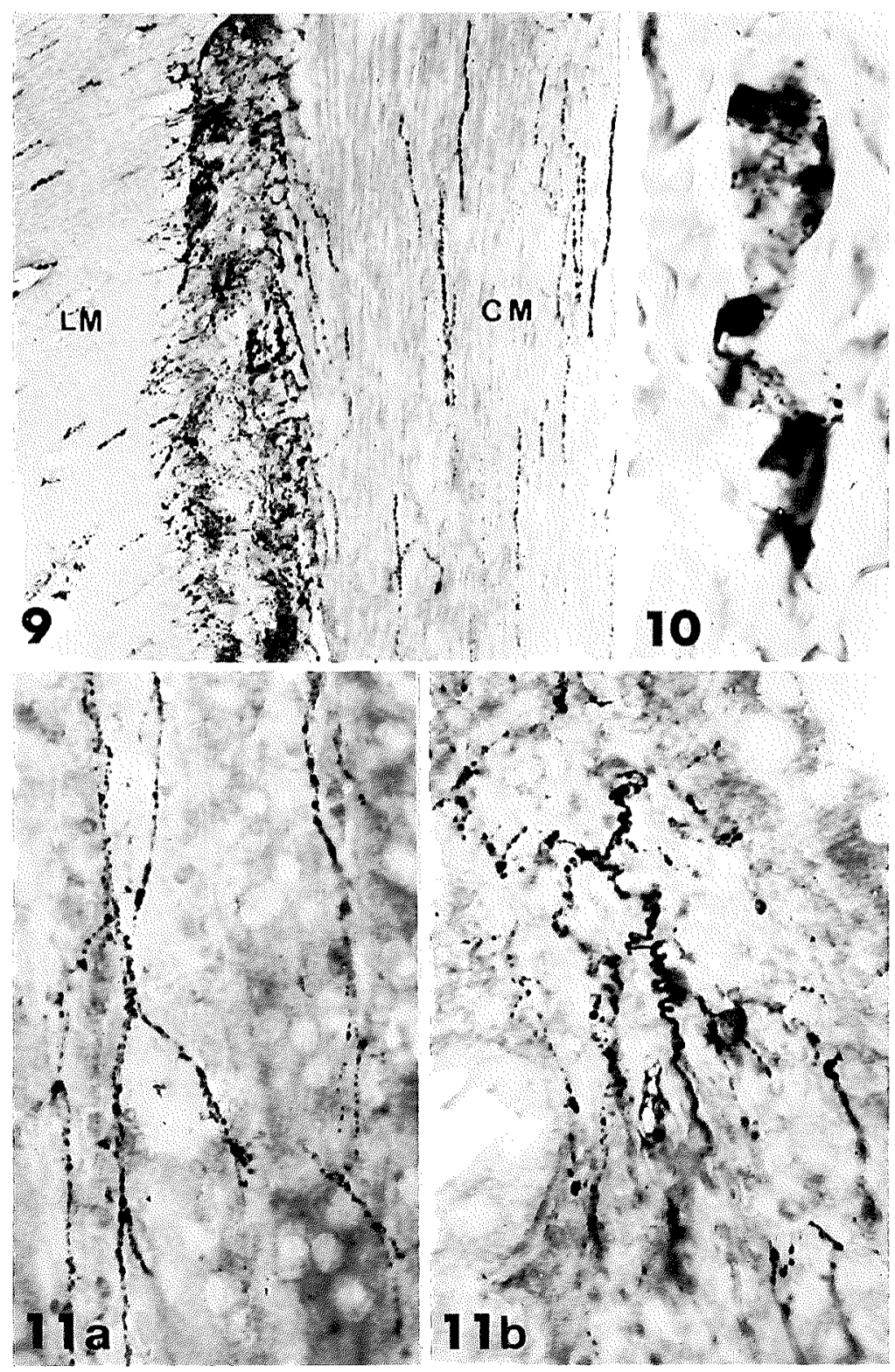

Figs. 9-11 Canine jejunal wall incubated with antiserum to VIP

Fig. 9 VIP-containing nerve fibers in the myenteric plexus between the longitudinal (LM) and circular (CM) muscle layer. Long beaded fibers run in the circular muscle layer, some continuous with the myenteric plexus. Varicose nerve fibers can be seen in the longitudinal muscle layer (LM). $\times 200$

Fig. 10 VIP containing neurons and varicose fibers of the submucosal ganglion. $\quad \times 400$

Fig. 11 a: Long beaded VIP nerve fibers form a periglandular plexus and run toward the villi. $\times 360$. $\mathrm{b}$ : A network of VIP fibers underneath the epithelium (subepithelial plexus). A fiber connection can be seen between the subepithelial and periglandular plexus. $\times 360$ 


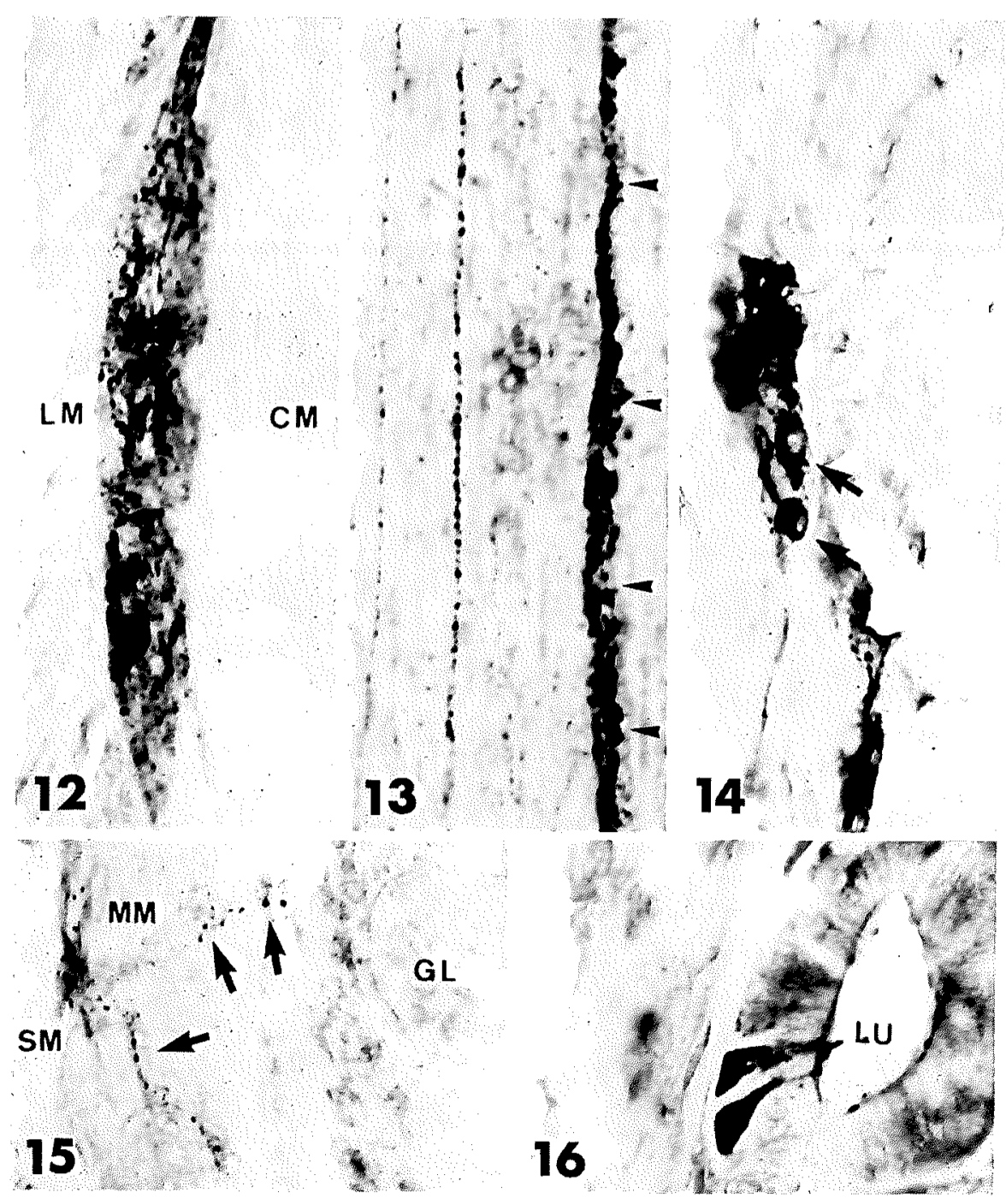

Figs. 12-15 Canine jejunal wall incubated with antisera to M-ENK

Fig. 12 A ganglion of the myenteric plexus between the longitudinal (LM) and circular (CM) muscle layer. M-ENK immunoreactive nerve fibers can be observed in the myenteric plexus. $\times 200$

Fig. 13 Long beaded M-ENK fibers in the circular muscle layer running parallel to the deep muscular plexus (arrowheads) where a thick M-ENK fiber bundle can be seen. $\times 200$

Fig. 14 Submucosal ganglion. Several M-ENK immunoreactive somata (arrows) can be seen. Due to the thickness of the section $(20 \mu \mathrm{m})$, only a few cell bodies are in focus. $\quad \times 200$

Fig. 15 Varicose M-ENK nerve fibers (arrows) in the muscularis mucosae (MM) beneath the jejunal glands (GL). $\times 200$

Fig. 16 Pyloric mucosa. Two M-ENK positive endocrine cell bodies are in the epithelium. LU, lumen. $\times 250$ 


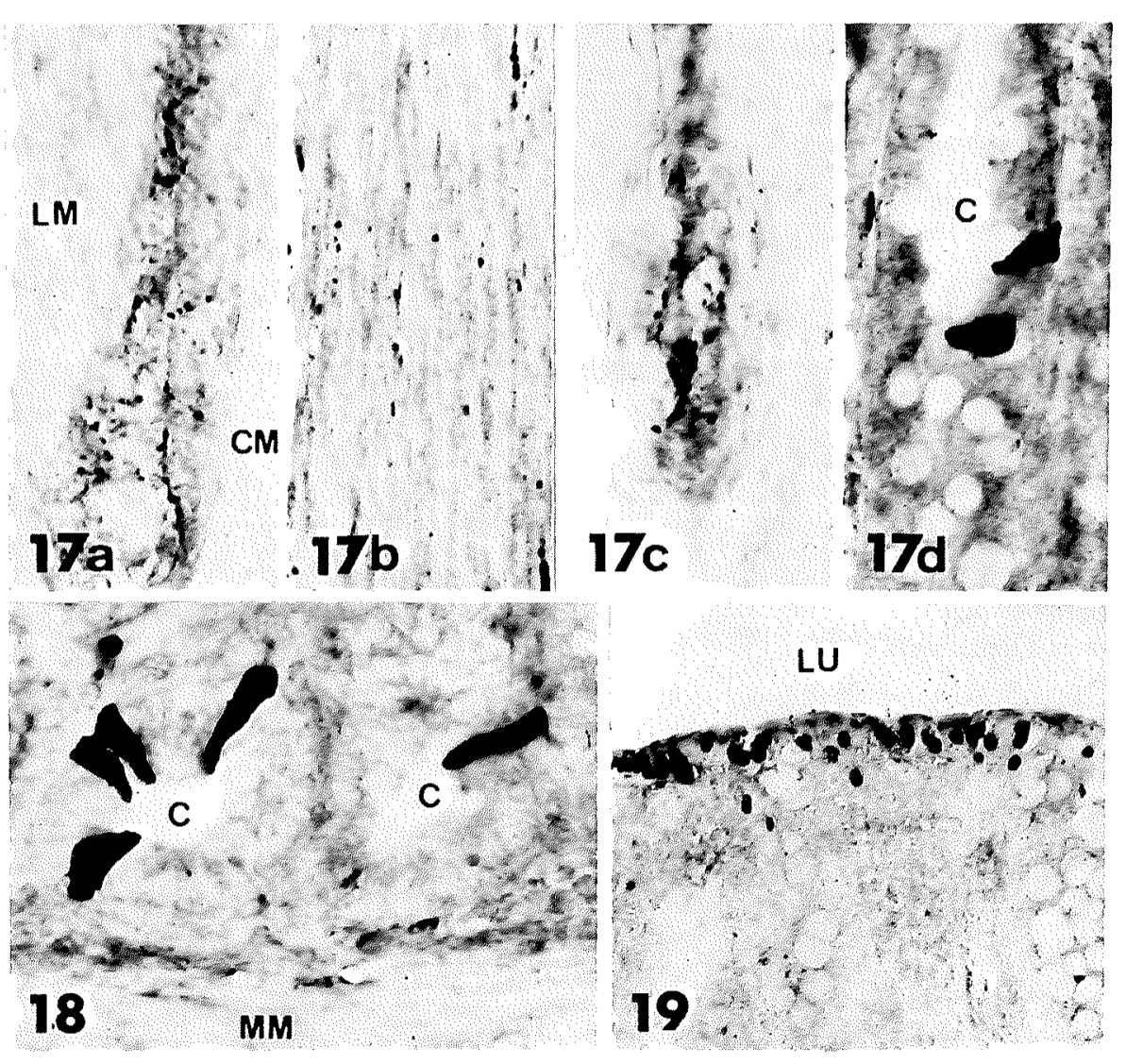

Fig. 17 Sections of the canine jejunal wall incubated with antisera to NT, a: A ganglion of the myenteric plexus between the longitudinal (LM) and circular (CM) muscle layers. Beaded NT nerve fibers and terminals surround the nerve cells of the myenteric plexus. $\times 200 . \quad \mathrm{b}: \mathrm{A}$ few NT positive nerve fibers in the circular muscle layer. $\times 200$. c: A few NT nerve fibers in the submucosal plexus. $\times 200$. d: Two NT positive endocrine cells in the epithelial layer of the jejunal gland. c, crypt. $\times 400$

Fig. 18 NT immunoreactive endocrine cells in the epithelial layer of the ileal glands. These cells are most abundantly found in the ileum. C, crypts; MM, muscularis mucosae. $\times 400$

Fig. 19 NT-like immunoreactivity in the epithelium of the colon. This immunoreativity is localized in a marginal zone of the mucosa when observed in a vertical section. LU, lumen. $\times 200$

3) peptides found only in endocrine cells. The first type includes SOM, M-ENK, and NT, and the second type, SP and VIP. The third type of peptides, however, was not observed in the present study. The finding that all the peptides studied are present in neuronal elements strongly suggests that they might have fundamental roles related to neuronal regulation.

The second type of peptides, SP and VIP, may be postulated to act as neurotransmitters or as neuromodulators which promote the fast conduction system in the digestive tract. On the other hand, the first type of peptides may give the character of paraneurons to the endocrine cells containing them. According to Fujita, the paraneuron is defined as a recepto-secretory cell which synthesizes substances identical with or related to neurohormones and neurotransmitters (17). In addition, Fujita has also proposed that an open type of gut endocrine cells, whose thick cytoplasmic extensions reach the gut lumen, can recognize chemical changes in the lumen (external milieu) and can respond to it by releasing messenger substances to the internal milieu (18). Hence, the endocrine cells reaching the gut lumen as described in this study fit the category of open type paraneurons. On the other hand, the SOM-containing endocrine cells 
in the gastric body are closed type paraneurons which are presumed to release their secretions from the tips of their cytoplasmic processes to the gastric gland cells. SOM cells of similar structure have been reported in the rat and human stomach $(1,34)$ and in the dog gastric body (32).

Concerning the third type of endocrine cells, our recent studies indicate that gastrin and motilin are located in endocrine cells, but not in neurons, of the canine gut (unpublished observation). Inasmuch as gastrin has been detected in neurons of rodent gut (48), only motilin is a possible peptide of the third type. In any event, all these peptides have been found in neurons of the central nervous system, and are justly termed 'brain-gut peptides'.

\section{Peptides in Endocrine Cells}

The present results are essentially in accordance with the previous descriptions of gut endocrine cells containing SOM, M-ENK, and NT in various mammals, including the dog. Here, only differing features will be discussed.

SOM In agreement with previous studies in the $\operatorname{dog}(3,44,46)$, SOM-containing endocrine cells were distributed in all parts of the gastrointestinal tract. Although no epithelial cells have been reported to be positively stained for SOM in the canine colon $(25,26)$, the present study demonstrates SOM-containing endocrine cells in this part of the gut. This discrepancy may be due to different immunohistochemical techniques or to the different antisera used. Except for this discrepancy, the present findings on the SOM positive structures are almost identical with previous observations, not only in the dog but also in various other mammals.

$M-E N K$ No significant difference was observed between our results and previous reports $(2,24)$.

$N T$ Although several studies have indicated that NT-containing endocrine cells were exclusively located in the small intestine, but not in the colon of the $\operatorname{dog}(16,20,25,40,52)$, the present study found NT-containing endocrine cells in the colon as well as in the small intestine.

$S P$ and VIP Neither SP nor VIP immunoreactive endocrine cells could be detected, whereas they have been found in the digestive tract of various mammals including the $\operatorname{dog}(9,10,38$, $41,43,53)$. This discrepancy may be due to different immunohistochemical techniques or to the different antisera used.

\section{Peptides in Neuronal Elements}

The distribution of different neuronal peptides varied considerably in different areas of the digestive tract (Diagram 1), in a way closely resembling that reported in other mammals (2, $11-15,22,27,33,35,38,48,53)$. SP and VIP immunoreactivity was the most abundant, whereas the immunoreactivity of M-ENK and SOM was scarcer and located only in discrete regions. Since neuronal cell bodies stained for each of the peptides, except NT, were found in the intramural ganglia, it is likely that the majority of fibers reactive to the peptides are intrinsic, i.e., derived from intramural ganglia. On the other hand, it is supposed that the potential targets for these neuropeptides are neurons in the myenteric or submucosal plexuses, smooth muscles, blood vessels, glands, and surface epithelium (54). The possible functions of the peptides in the canine gut are as follows.

SOM There were moderate densities of SOM-containing neuronal elements in and around neuronal ganglia, and low to very low densities in the smooth muscle layers and in the lamina propria. These results are in good agreement with physiological studies which report that the peptide inhibits the firing of neurons (57) and that it has little or no direct effect on the intestinal smooth muscles (19).

$M$-ENK Neuronal cell bodies immunoreactive for this peptide were often observed in the ganglia of the submucosal plexus in the small intestine and the colon of the dog, but such structures either have not been found or have been seen only in a definite region of the corresponding plexus in other species $(15,27,35$, 48). This suggests that M-ENK-containing neurons in the submucosal ganglia may have inhibitory roles similar to those found in the myenteric plexus (39). Like other mammals, the dog has a considerable amount of M-ENKpositive neuronal fibers in the smooth muscle layers and the lamina propria in the gut. A marked influence on myoelectric activities by $\mathrm{M}$ ENK in the dog intestine has been demonstrated (31), though the role of M-ENK in the mucosa is unclear.

$N T$ Sparsely distributed NT fibers were observed in the small intestine of the dog, especially in the myenteric plexus of the jejunum and ileum. Schultzberg et al. (48) reported the occurrence of NT in the rat digestive tract. Like the rodents, the dog does not seem to have neuronal somata in the intestinal wall. On the other hand, Saffrey et al. (47) have demonstrated 
the existence of NT positive neuronal somata in the myenteric plexus of the embryonic chicken gut. In such immature animals NT may be accumulated in the perikarya of the enteric nervous system. A further study is required in mammalian fetuses.

$S P \quad$ No special difference is seen in the pattern of distribution of SP between the dog and other species reported $(11,13,27,38,48,53)$. This peptide causes an atropin-resistant contraction of smooth muscles (59). Such an effect on the muscles is thought to be promoted by both direct and indirect (transneuronal) effect of SP, since SP is also known to depolarize myenteric neurons (28). These functional roles of SP are consistent with the results obtained by immunohistochemistry.

$V I P$ This peptide in the dog digestive tract is distributed similarly to that in other species reported $(12,27,33,48)$. Like SP, VIP also affects both smooth muscles $(8,42,55,56)$ and neuronal somata of myenteric ganglia (58), though its actions on muscles are the reverse of those of SP.

In addition, Schultzberg et al. (48) suggested that the dense fiber networks of ENK, SP, and VIP in the lamina propria might play a role in blood flow regulation, that at least in part they represent peripheral branches of sensory afferents. Further details of the roles of these fibers need to be elucidated. The presence of neuronal short fibers in close proximity to epithelial cells may suggest that such fibers containing VIP as well as SP and M-ENK have influence on the exocrine secretion in the gut.

The support of Professor I. Hashimoto, Second Department of Surgery, Professor Y. Ibata, Second Department of Anatomy, Kyoto Prefectural University of Medicine, Kyoto, Japan and Associate Professor H. Kimura, Department of Anatomy, Shiga University of Medical Science, Shiga, Japan, is gratefully acknowledged.

I thank Professor N. Yanaihara, Laboratory of Bioorganic Chemistry, Shizuoka College of Pharmacy, Shizuoka, Japan, for the generous supply of synthetic VIP and antisera to VIP and neurotensin and Otsuka Assay Laboratory, Tokushima, Japan, for kindly supplying antiserum to somatostatin.

I also acknowledge the kind help of Dr T. Matsuura, Department of Anatomy, Dr K. Fukui, Department of Neuropsychiatry, and Dr Y. Hisa, Department of Otolaryngology, Kyoto Prefectural University of Medicine, Kyoto, Japan.

Received for publication 5 July 1982; and in revised form 20 December 1982

\section{REFERENCES}

1. Alumets J., Ekelund M., Munshid H. A. El., HÅKanson R., LoRén I, and Sundler F. (1979) Topography of somatostatin cells in the stomach of the rat: Possible functional significance. Cell Tissue Res. 202, 177-188

2. Alumets J., HÅkanson R., Sundler F. and CHANG K.-J. (1978) Leu-enkephalin-like material in nerves and enterochromaffin cells in the gut: An immunohistochemical study. Histochemistry 56, 187-196

3. Alumets J., Sundler F. and HÅkanson R. (1977) Distribution, ontogeny and ultrastructure of somatostatin immunoreactive cells in the pancreas and gut. Cell Tissue Res. 185, 465-479

4. Andersson S., Chang D., Folkers K. and Rosell S. (1976) Inhibition of gastric acid secretion in dogs by neurotensin. Life Sci. 19, 367370

5. Andersson S., Rosell S., Hjelmquist U., Chang D. and Folkers K. (1977) Inhibition of gastric and intestinal motor activity in dogs by $\left(\mathrm{Gln}^{4}\right)$ neurotensin. Acta Physiol. Scand. 100, 231-235

6. Barros D'Sa, A. A. J., Bloom S. R. and Baron J. H. (1975) Direct inhibition of gastric acid by growth-hormone release-inhibiting hormone in dogs. Lancet I, 886-887

7. BLoom S. R. and PolaK J. M. (ed.) (1981) Gut Hormones Second Ed., Churchill Livingstone, Edinburgh/London/Melbourne/New York

8. Bodanszky M., Klausner Y. S. and Said S. I. (1973) Biological activities of synthetic peptides corresponding to fragments of and to the entire sequence of the vasoactive intestinal peptide. Proc. Natl. Acad. Sci. USA 70, 382-384

9. Bryant M. G., Bloom S. R., Polak J. M., Albuquerque R. H., Modlin I. and Pearse A. G. E. (1976) Possible dual role for vasoactive intestinal peptide as gastrointestinal hormone and neurotransmitter substance. Lancet I, 991993

10. Buffa R., Capella C., Solcia E., Frigerio B. and SAID S. I. (1977) Vasoactive intestinal peptide (VIP) cells in the pancreas and gastrointestinal mucosa. An immunohistochemical and ultrastructural study. Histochemistry 50, 217-227

11. Costa M., Cuello A. C., Furness J. B. and FRANCO R. (1980) Distribution of enteric neurons showing immunoreactivity for substance $P$ in the guinea-pig ileum. Neuroscience 5, 323-331

12. Costa M., Furness J. B., Buffa R. and Said S. I. (1980) Distribution of enteric nerve cell bodies and axons showing immunoreactivity for vasoactive intestinal polypeptide in the guinea-pig intestine. Neuroscience 5, 587-596

13. Costa M., Furness J. B., Llewellyn-Smith I. J. and Cuello A. C. (1981) Projections of substance $\mathrm{P}$-containing neurons within the guinea- 
pig small intestine. Neuroscience 6, 411-424

14. Costa M., Furness J. B., Llewellyn Smith I. J., Davies B, and Oliver J. (1980) An immunohistochemical study of the projections of somatostatin-containing neurons in the guinea-pig intestine. Neuroscience 5, 841-852

15. EldE R., HöKfElt T., Johansson $O$. and TEREnIUs L. (1976) Immunohistochemical studies using antibodies to leucine-enkephalin: Initial observations on the nervous system of the rat. Neuroscience 1, 349-351

16. Frigerio B., Ravazola M., Ito S., Buffa R., Capella C., Solcia E. and OrCI L. (1977) Histochemical and ultrastructural identification of neurotensin cells in the dog ileum. Histochemistry 54, 123-131

17. Fujita T. (1977) Concept of paraneurons. Arch. histol. japon. 40, Suppl., 1-12

18. Fujlta T. and Kobayashi S. (1981) The endocrine cell. In Gut Hormones Second Ed. (ed. Bloom S. R. and PolaK J. M.) Churchill Livingstone, Edinburgh/London/Melbourne/NewYork, pp. 90-95

19. Furness J. B. and Costa M. (1980) Types of nerves in the enteric nervous system. Neuroscience 5, 1-20

20. Helmstaedter V., Taugner Ch., Feurle G. E. and ForssmanN W. G. (1977) Localization of neurotensin-immunoreactive cells in the small intestine of man and various mammals. Histochemistry 53, 35-41

21. Hökfelt T., Efendić S., Hellerström C., Johansson O., Luft R. and Arimura A. (1975) Cellular localization of somatostatin in endocrine-like cells and neurons of the rat with special references to the $A_{1}$-cells of the pancreatic islets and to the hypothalamus. Acta Endocrinol. Suppl. 200, 5-41

22. Hökfelt T., Johansson O., Efendić S., Luft R. and Arimura A. (1975) Are there somatostatincontaining nerves in the rat gut? Immunohistochemical evidence for a new type of peripheral nerves. Experientia 31, 852-854

23. Hökfelt T., Johansson O., LJungdahl A., Lundberg J. M. and Schultzberg M. (1980) Peptidergic neurones. Nature 284, 515-521

24. Ito S., Takai K., Shibata A., Matsubara Y. and YanalHara N. (1979) Met-enkephalin-immunoreactive and gastrin-immunoreactive cells in the human and canine pyloric antrum. Gen. Comp. Endocrinol. 38, 238-245

25. Ito S., Yamada Y., Hayashi M., Iwasaki Y., Matsubara Y. and Shibata A. (1979) Neurotensin-positive and somatostatin-positive cells in the canine gut. Tohoku J. Exp. Med. 127, 123-131

26. Ito S., Yamada Y. and Kobayashi S. (1977) Immunohistochemical demonstration of somatostatin-positive cells in the canine gut. Tohoku J. Exp. Med. 121, 85-90

27. Jessen K. R., SAfFrey M. J., VAN Noorden S.,
Bloom S. R., Polak J. M. and Burnstock G. (1980) Immunohistochemical studies of the enteric nervous system in tissue culture and $i n$ situ: Localization of vascoactive intestinal polypeptide (VIP), substance-P and enkephalin immunoreactive nerves in the guinea-pig gut. Neuroscience 5, 1717-1735

28. Katayama Y. and North R. A. (1978) Does substance $\mathrm{P}$ mediate slow synaptic excitation within the myenteric plexus? Nature 274, 387388

29. Kimura H., McGeer P. L., Peng J. H. and MCGeER E. G. (1981) The central cholinergic system studied by choline acetyltransferase immunohistochemistry in the cat. J. Comp. Nelirol. 200, 151-201

30. Konturek S. J., Tasler J., Cieszkowski M., Mikoś E., Coy D. H. and Schally A. V. (1980) Comparison of methionine-enkephalin and morphine in the stimulation of gastric acid secretion in the dog. Gastroenterology 78, 294-300

31. Konturek S. J., Thor P., Król R., Dembiński A. and Schally A. V. (1980) Influence of methionine-enkephalin and morphine on myoelectric activity of small bowel. Amer. J. Phy siol. 238, G384-G389

32. Kusumoto Y., Iwanaga T., Ito S. and FujITA T. (1979) Juxtaposition of somatostatin cell and parietal cell in the dog stomach. Arch. histol. japon. 42, 459-465

33. Larsson L.-I., Fahrenkrug J., Schaffalitzky De Muckadell O., Sundler F., Håkanson R. and REHFELD J. F. (1976) Localization of vasoactive intestinal polypeptide (VIP) to central and peripheral neurons. Proc. Natl. Acad. Sci. USA 73, 3197-3200

34. Larsson L.-I., Goltermann N., De Magistris L., Rehfeld J. F. and Schwartz T. W. (1979) Somatostatin cell processes as pathways for paracrine secretion. Science 205, 1393-1395

35. Linnoila R. I., Diaugustine R. P., Miller R. J., Chang K. J. and Cuatrecasas P. (1978) An immunohistochemical and radioimmunological study of the distribution of [Met $\left.{ }^{5}\right]-$ and [Leu $\left.{ }^{5}\right]$ enkephalin in the gastrointestinal tract. Neuroscience 3, 1187-1196

36. Milenov K., Oehme P., Bienert M. and BergMANN J. (1978) Effect of substance P on mechanical and myoelectrical activities of stomach and small intestines in conscious dog. Arch. Int. Pharmacodyn. Ther. 233, 251-260

37. Morgan K. G., Schmalz P. F. and Szurszewski J. H. (1978) The inhibitory effects of vasoactive intestinal polypeptide on the mechanical and electrical activity of canine antral smooth muscle. J. Physiol. 282, 437-450

38. Nilsson G., LaRsSON L.-I., HÅKanson R., Brodin E., Pernow B. and Sundler F. (1975) Localization of substance P-like immunoreactivity in mouse gut. Histochemistry 43, 97-99

39. North R. A. and Williams J. T. (1976) Enkeph- 
alin inhibits firing of myenteric neurones. Nature 264, 460-461

40. Orci L., Baetens O., Rufener C., Brown M., VAle W. and Guillemin R. (1976) Evidence for immunoreactive neurotensin in dog intestinal mucosa. Life Sci. 19, 559-562

41. Pearse A. G. E. and Polak J. M. (1975) Immunocytochemical localization of substance $P$ in mammalian intestine. Histochemistry 41, 373375

42. Piper P. J., Said S. I. and Vane J. R. (1970) Effects on smooth muscle preparations of unidentified vasoactive peptides from intestine and lung. Nature 225, 1144-1146

43. Polak J. M., Pearse A. G. E., Garaud J.-C. and BLOOM S. R. (1974) Cellular localization of a vasoactive intestinal peptide in the mammalian and avian gastrointestinal tract. Gut 15, 720724

44. Polak J. M., Pearse A. G. E., Grimelius L., Bloom S. R. and Arimura A. (1975) Growthhormone release-inhibiting hormone in gastrointestinal and pancreatic D cells. Lancet $\mathbf{I}$, 1220-1222

45. Reinecke M., Almasan K., Carraway R. Helmstaedter V. and Forssman N. W. G. (1980) Distribution patterns of neurotensin-like immunoreactive cells in the gastro-intestinal tract of higher vertebrates. Cell Tissue Res. 205, 383395

46. Rufener C., Dubois M. P., Malaisse-Lagae F. and ORCI L. (1975) Immuno-fluorescent reactivity to anti-somatostatin in the gastro-intestinal mucosa of the dog. Diabetologia 11, 321-324

47. Saffrey M. J., Polak J. M. and Burnstock G. (1982) Distribution of vasoactive intestinal polypeptide-, substance $\mathrm{P}$-, enkephalin- and neurotensin-like immunoreactive nerves in the chicken gut during development. Neuroscience 7, 279-293

48. Schultzberg M., Hökfelt T., Nilsson G., Terenius L., Rehfeld J. F., Brown M., Elde R., GoldSTEIN M. and SAID S. (1980) Distribution of peptide- and catecholamine-containing neurons in the gastro-intestinal tract of rat and guineapig: Immunohistochemical studies with anti- sera to substance $P$, vasoactive intestinal polypeptide, enkephalins, somatostatin, gastrin/cholecystokinin, neurotensin and dopamine $\beta$-hydroxylase. Neuroscience 5, 689-744

49. Schusdziarra V., Zyznar E., Rouiller D., HARris V. and UNGer R. H. (1980) Free somatostatin in the circulation: Amounts and molecular sizes of somatostatin-like immunoreactivity in portal, aortic, and vena caval plasma of fasting and meal-stimulated dogs. Endocrinology 107, 1572-1576

50. Sternberger L. A. (1979) Immunocytochemist'y Second Ed., J. Wiley, New York

51. Straus W. (1979) Peroxidase procedures. Technical problems encountered during their application. J. Histochem. Cytochem. 27, 1349-1351

52. Sundler F., Håkanson R., Hammer R. A., Alumets J., Carraway R., Leeman S. E. and ZimMERMAN E. A. (1977) Immunohistochemical localization of neurotensin in endocrine cells of the gut. Cell Tissue Res. 178, 313-321

53. Sundler F., HÅkanson R., Larsson L.-I., Brodin E. and Nilsson G. (1977) Substance P in the gut: An immunochemical and immunohistochemical study of its distribution and development. In Substance $P$ (ed. von Eular U. S. and Pernow B.) Raven Press, New York, pp. 59-65

54. Sundler F., HÁKanson R. and Leander S. (1980) Peptidergic nervous systems in the gut. Clinics in Gastroenterol. 9, 517-543

55. Szurszewski J. (1978) Hormonal control of gastric contractions in the dog and human. Jap. J. Smooth Musc. Res. 14, Suppl., 21-24

56. Uddman R., Alumets J., Edvinsson L., HÅkansON R. and Sundler F. (1978) Peptidergic (VIP) innervation of the esophagus. Gastroenterology 75, 5-8

57. Williams J. T. and North R. A. (1978) Inhibition of firing of myenteric neurones by somatostatin. Brain Res. 155, 165-168

58. Williams J. T. and North R. A. (1979) Vasoactive intestinal polypeptide excites neurones of the myenteric plexus. Brain Res. 175, 174-177

59. YAU W. M. (1978) Effect of substance P on intestinal muscle. Gastroenterology 74, 228-231 